\title{
In vitro and in vivo gene transfer to pulmonary cells mediated by cationic liposomes
}

\author{
Elisabetta Fortunati ${ }^{\mathrm{a}, \mathrm{b}, *}$, Abraham Bout ${ }^{\mathrm{b}}$, Maria Antonia Zanta ${ }^{\mathrm{a}}$, Dinko Valerio ${ }^{\mathrm{b}, \mathrm{c}}$, \\ Maurizio Scarpa ${ }^{\text {a }}$ \\ ${ }^{a}$ Centro per il Trasferimento Genico, Department of Pediatrics, CRIBI Biotechnology Center, 35100 Padova, Italy \\ ${ }^{b}$ IntroGene BV, Rijswijk, The Netherlands \\ ' Working Group Gene Therapy, Department of Medical Biochemistry, University of Leiden, Leiden, The Netherlands
}

Received 31 July 1995; revised 31 October 1995; accepted 17 November 1995

\begin{abstract}
Cationic liposomes have been proposed as alternative to adenovirus in the treatment of cystic fibrosis lung desease. Therefore, we have investigated the efficiency of two lipid mixtures in mediating gene transfer in in vitro and in vivo models. The cationic lipid DOTMA ( $N$-(1-(2,3(dioleyloxy)propyl)-n,n,n-trimethylammoniumchloride) and DOGS (dioctadecylamidoglycylspermine) were used in combination with the neutral lipid DOPE (dioleoylphosphatidylethanolamine). The relative transfection efficiencies of the two cationic liposomes were tested using the bacterial $\beta$-galactosidase (lacZ) and the firefly luciferase genes. Gene expression was detected in both cell lines and primary culture of rhesus monkey airway epithelium after transfection with plasmid DNA complexed with DOGS/DOPE or DOTMA/DOPE. Transfection efficiency of both types of lipids was higher in the mouse fibroblast 3T3 cell line as compared to human carcinoma A549 cells and primary epithelial cultures. Administration of DNA-liposome complexes via intratracheal instillation resulted in expression of the lacZ and luciferase marker gene in the mouse airways. In vivo transfection mediated by both types of liposomes were proven to be far less efficient than adenovirus treatment.
\end{abstract}

Keywords: Cationic lipid; Gene transfer; (Lung)

\section{Introduction}

Efficient introduction and expression of corrected genes into airway epithelium are the major goals in human Cystic Fibrosis (CF) gene therapy. There are several technologies available for human gene transfer to lungs. Currently, the preferred method for gene transfer to pulmonary cells involves recombinant adenovirus because of their ability to achieve high transfection efficiency $[1,2]$. However, this method has the disadvantage to cause inflammatory reactions in the lung that may lead to pulmonary damage in CF patients [2-5]. Compared to recombinant adenoviruses, cationic liposomes seem relatively save vectors because they are not toxic after introduction into experimental animals [6].

However, it is not equivocally established which lipid

\footnotetext{
* Corresponding author. Present address: Department of Cell Biology I, Erasmus University, 3000 DR Rotterdam, The Netherlands. Fax: +3110 4360225; e-mail: fortunati@ch.fgg.eur.nl.
}

composition is optimal for an efficient gene transfer. Since the various reports on this subject each apply only one liposome formulation [6-11], it is very difficult to assess the effect of lipid composition of the liposomes on gene transfection efficiency.

In this study the transfection efficiencies of two lipids, DOTMA and DOGS, were compared in a direct manner. These two lipids differ from each other in the way they interact with DNA [12]. DOGS is a lipid of which the headgroups interact strongly with the minor groove of DNA via the polyamine group. In excess of DOGS, a nucleosome-type structure is formed in which the DNA molecule is packaged $[13,14]$. In contrast, DOTMA in aqueous solution forms liposomes which aggregate spontaneously with the negatively charged DNA molecules [15]. To optimally compare the two lipids, experimental conditions were chosen in a way that DNA-liposome ratios were equal for DOGS and DOTMA. Transfection efficiency was assessed with the use of marker genes ( $\beta$-galactosidase and luciferase) in established cell lines as well as primary 
culture of monkeys trachea explants. Furthermore, gene expression was evaluated after in vivo intratracheal instillation of DNA/DOTMA or DNA/DOGS in mice.

\section{Materials and methods}

\subsection{Plasmids}

In this study E. coli lacZ and Photinus pyralis luciferase genes were used as reporters. Using a pUC19 backbone [16] we obtained a pCMVNLS/lacZ (Fig. 1a) and a pCMV/luc (Fig. 1b) gene expression plasmid vector. From pRSV/luc plasmid [17] (Fig. 1c) we obtained a pRSVNLS/lacZ (Fig. 1d). The reporter genes in vector $a, b$ were under the control of the human cytomegalovirus immediate early gene promotor [18]. In the experiments with monkey trachea epithelium primary cultures we used a pCMVNLS/lacZ (Fig. 1e) [6].

\subsection{DNA manipulations}

DNA manipulations were performed according to [19]. The plasmids were propagaled in $E$. coli $\mathrm{DH} 5 \alpha$ and plasmid DNA was isolated using an alkaline lysis method
[19] and purified with two CsCl-ethidium bromide density gradients. The obtained DNA was dialyzed against bidistilled water overnight.

\subsection{Recombinant adenovirus}

Ad.CMV/luc virus [20] was used as positive control in the animal experiments. The recombinant virus based on adenovirus type 5 (Ad5) is E1 region deficient and therefore unable to replicate in non-competent cells [21]. The virus was propagated in 293 cells according to the standard procedures [22]. Two mice received via intratracheal instillation $100 \quad \mu \mathrm{l}$ solution containing $10^{8} \mathrm{pfu}$ of the Ad.CMV/luc virus.

\subsection{Cell cultures}

\subsubsection{Cell lines}

A549 and 3T3 cell lines were cultured in $25 \mathrm{~cm}^{2}$ flasks (Nunc products, Roskilde, Denmark) in Dulbecco's modified Eagle's medium (DMEM) supplemented with $10 \%$ of foetal calf serum (Gibco), $100 \mu \mathrm{g} / \mathrm{ml}$ streptomycin, 100 $\mathrm{IU} / \mathrm{ml}$ penicillin and $1 \mathrm{mM}$ glutamine at $37^{\circ} \mathrm{C}$ in a humidified atmosphere containing $5 \% \mathrm{CO}_{2}$. At confluence the A549 and the 3 T 3 cells were trypsinized and seeded in
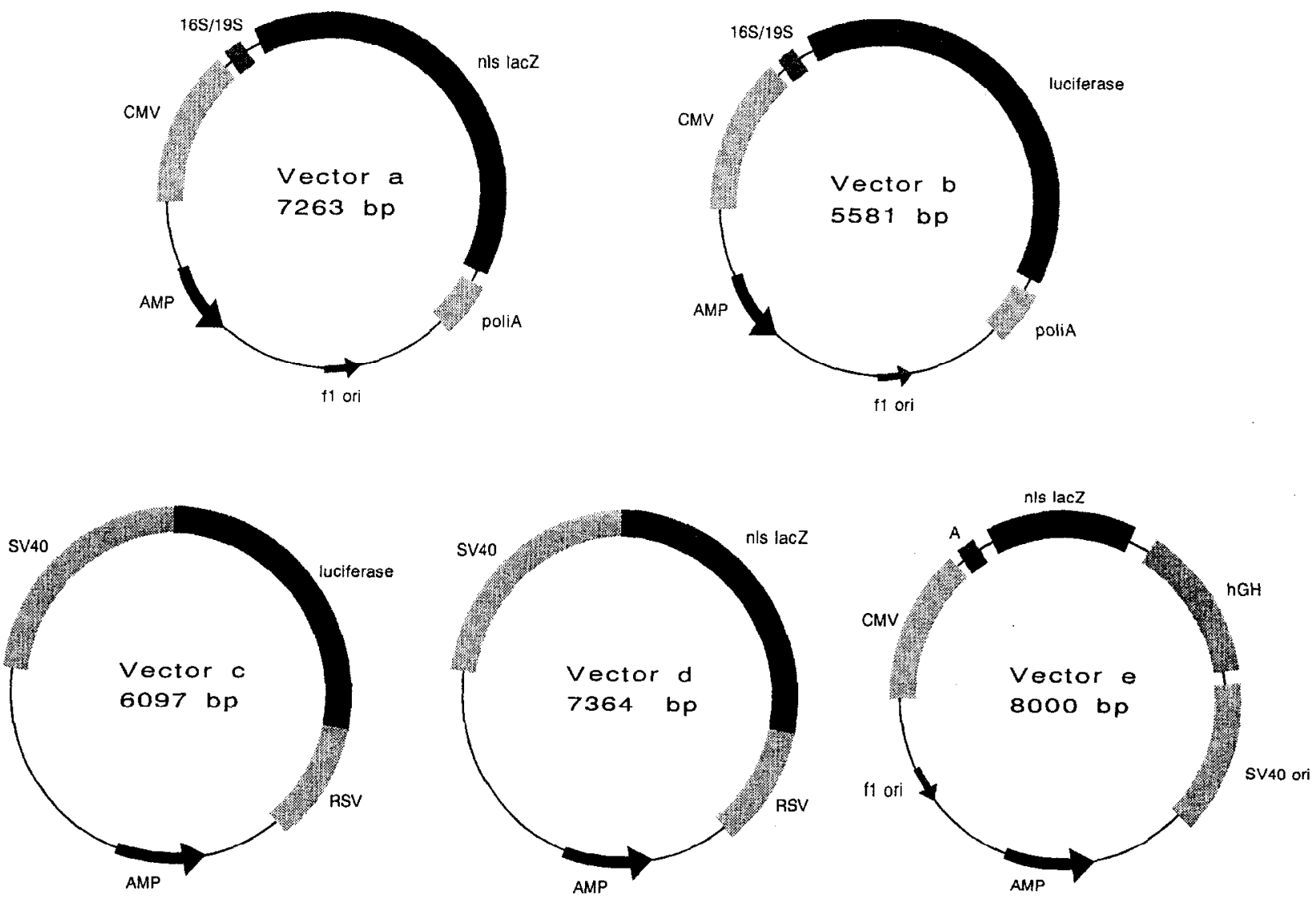

Fig. 1. Plasmid vectors used for gene transfer in cell lines (a,c), primary trachea cultures (c,e) and in vivo (a,b,c,d). The details of the plasmid construction are given in Section 2. 
six well plates at densities of 0.2 and $0.4 \cdot 10^{6}$, respectively. In our hands, the cell cycle time of A549 and 3T3 cells was 24 and $12 \mathrm{~h}$, respectively.

\subsubsection{Primary cultures of monkey airway epithelium}

The respiratory epithelium was obtained from Rhesus monkeys (Macaca mulatia) that were killed for kidney transplantation experiments at TNO Biomedical Primate Research Center, Rijswijk, The Netherlands. After excision, the trachea was immersed in PBS and transferred within $10 \mathrm{~min}$ to the laboratory where the connective and lymphatic tissue was removed. The trachea was washed thoroughly with PBS supplemented with $1 \mu \mathrm{g} / \mathrm{ml}$ of amphothericin C and with RPMI 1640 medium containing $25 \mathrm{mM}$ Hepes, $100 \mathrm{U} / \mathrm{ml}$ penicillin and $100 \mu \mathrm{g} / \mathrm{ml}$ streptomycin. Tracheal epithelial explants were isolated essentially according to the method described by [23]. Briefly, the dorsal part of the tracheal tissue was removed and cut into pieces of $2-3 \mathrm{~mm}^{2}$. The explants, selected for the presence of active ciliary beating by light microscopy, were seeded in 24 well plates (Nunc) coated with human collagen Type IV (Sigma). Each well was coated with 10 $\mu \mathrm{g} / \mathrm{cm}^{2}$ of collagen gel solution. The explants were covered with a minimum amount of serum-free culture medium (0.2-0.3 ml) composed by RPMI supplemented with 1 $\mu \mathrm{g} / \mathrm{ml}$ insulin, $1 \mu \mathrm{g} / \mathrm{ml}$ transferrin, $10 \mathrm{ng} / \mathrm{ml} \mathrm{EGF}$ and $0.5 \mu \mathrm{g} / \mathrm{ml}$ hydrocortisone. The culture chamber was kept at $37^{\circ} \mathrm{C}$. Each experiment was performed using trachea cultures derived from the same monkey.

\subsection{Cationic liposomes}

DOTMA ( $N$-(1-(2,3-dioleyloxy)propyl)- $n, n, n$-trimethylammoniumchloride) (Lipofectin ${ }^{\mathrm{TM}}$, Gibco BRL) and the lipopolyamine DOGS (dioctadecylamidoglycylspermine) with the neutral lipid DOPE (dioleoylphosphatidylethanolamine) were used as transfection agents for in vitro and in vivo experiments. The lipids DOGS and DOPE were a gift of Dr. J.P. Behr (Laboratoire de Chimie Génétique, Université Louis Pasteur, Strasbourg, France). Stock solutions of DOGS and DOPE were prepared in $10 \%$ ethanol solutions at final concentrations of $2 \mathrm{mM}$ and stored at $4^{\circ} \mathrm{C}$.

\subsection{In vitro transfection}

DOGS/DOPE transfection solutions were prepared as follows: 1 to $10 \mu \mathrm{g}$ of plasmid DNA were diluted in 150 $\mu l$ of a $150 \mathrm{mM} \mathrm{NaCl}$ solution ( $\mathrm{pH} 7.4$ ). For each $\mu \mathrm{g}$ of DNA 1 equivalent DOGS and 2-3 equivalents DOPE were added. The solution of DNA and DOGS-DOPE was mixed in a polystyrene tube and the DNA-lipid complex allowed to form for $10 \mathrm{~min}$ at room temperature. DOTMA/DOPE transfection mixture was prepared according to the instruction of the supplier. The cells, rinsed with unsupplemented medium, were exposed to the transfection solution $(1 \mathrm{ml}$ final volume) for 6-7 h. After transfection, the mixtures were removed and $2 \mathrm{ml}$ of culture medium was added.

\subsection{In vivo transfection}

Female 12-week-old Balb/c mice were used for the in vivo experiments. The body weight of the animals before the intratracheal instillation was about $18 \mathrm{~g}$. Plasmid DNA/liposome complexes or recombinant adenovirus were administered to mice intratracheally as described by Thepen et al. [24]. After anesthesia with 2.5\% Avertin (Aldrich), an incision was made to visualize the trachea and $100 \mu \mathrm{l}$ of the liposome transfection mixture or the adenovirus solution was injected into the trachea just above the bifurcation.

\subsection{Detection of $\beta$-galactosidase activity}

In vitro evaluation of lacZ gene expression was performed $36 \mathrm{~h}$ after DNA/liposome exposure. The cells were fixed in a $0.2 \%$ glutaraldehyde $/ 2 \%$ paraformaldehyde solution for $30 \mathrm{~min}$ at $4^{\circ} \mathrm{C}$ and stained overnight with X-gal (Sigma) as described by $[1,6]$. The number of $\mathrm{X}$-gal positive cells relative to the total number, was determined in a total of 2000 cells. The detection of X-gal positive cells in mouse airways was carried out $48 \mathrm{~h}$ after instillation. Lungs and trachea were removed and fixed for $1 \mathrm{~h}$ as described above. The organs were washed thoroughly with PBS and incubated with the $\mathrm{X}$-gal solution overnight.

Subsequently, the tissue was incubated with Karnovsky fixative and cmbedded in paraffin. $4 \mu \mathrm{m}$ sections were counterstained with hematoxylin, phloxin and saphran. Sections at different depth were analyzed by light microscopy for the expression of the lac $\mathrm{Z}$ gene.

\subsection{Detection of luciferase activity}

The luciferase activity in in vitro transfected cells was assessed $36 \mathrm{~h}$ after exposure to the transfection solution. The cells were washed 3 times with PBS and incubated in a Tris-EDTA- $\mathrm{NaCl}$ solution $(0.04 \mathrm{M}$ Tris- $\mathrm{HCl} \mathrm{pH} 7.4,1$ mM EDTA, $0.15 \mathrm{M} \mathrm{NaCl}$ ). The cells were detached with a policeman and after centrifugation the pellets were resuspended in lysis buffer (LBB) ( $0.1 \mathrm{M} \mathrm{Na}$ phosphate buffer pH 7.8, $8 \mathrm{mM} \mathrm{MgCl}_{2}, 1 \mathrm{mM}$ EDTA, $1 \mathrm{mM}$ DTT, $1 \%$ Triton X-100, $15 \%$ glycerol). The luciferase activity in the lysate was measured using a mix composed of LBB supplemented with $0.5 \mathrm{mM}$ ATP, $1 \mathrm{mM}$ Luciferin (Boehringer), $2 \% \mathrm{BSA}$ and $0.5 \mathrm{mM}$ phenylmethylsulfonyl fluoride (Sigma).

In mice, luciferase activity was assessed $48 \mathrm{~h}$ after instillation. The animals were killed by i.p. overdose of avertin (Aldrich). Lungs and trachea were removed after perfusion with $0.1 \mathrm{M}$ phosphate buffer by heart puncture. The tissues were disrupted in phosphate buffer with a 
Table 1

Expression of CMVNLS/lacZ plasmid in 3 T3 and A549 cell lines transfected with cationic liposomes ${ }^{\text {a }}$

\begin{tabular}{|c|c|c|c|c|}
\hline \multirow[t]{2}{*}{ DNA $(\mu \mathrm{g})$} & \multicolumn{2}{|c|}{ DOGS/DOPE } & \multicolumn{2}{|c|}{ DOTMA/DOPE } \\
\hline & $3 \mathrm{~T} 3 \%(\mathrm{SD})$ & A549\%(SD) & $3 \mathrm{~T} 3 \%(\mathrm{SD})$ & A549\%(SD) \\
\hline 2 & $3.1(1.1)$ & $0.1(0.1)$ & $2.7(1.4)$ & $0.3(0.1)$ \\
\hline 5 & NT & $0.6(0.2)$ & NT & $1.7(0.6)$ \\
\hline 10 & $15.0(4.6)$ & $2.1(0.3)$ & $18.3(7.7)$ & $3.0(2.3)$ \\
\hline
\end{tabular}

a Transfection efficiency is expressed as percentage of lacZ-positive cells (mean of three independent experiments \pm S.D.).

NT, not tested.

tissue mincer and lysed by adding $0.1 \%$ Triton $\mathrm{X}-100$ and $1 \mathrm{mM}$ dithiothreitol. The supernatants recovered after centrifugation were assayed for luciferase activity with $1 \mathrm{mM}$ $\mathrm{MgCl}_{2}, 1.25 \mathrm{mM} \mathrm{ATP}$, and $3 \mathrm{mM}$ luciferin. The luciferase activity in the cells and in mouse lungs was measured in a luminometer (LUMAC, Biocounter M2500) and expressed as relative light units per $\mathrm{mg}$ of protein.

The protein content in the lysate was determined according to the method of [25] using serum bovine albumin as standard.

\section{Results}

\subsection{Transfection conditions}

The ratio between DNA and liposomes is an important factor that influences transfection efficiency. In our study the transfection efficiency of non-charged DNA/liposome particles, containing a neutral lipid (DOPE), was assessed. Neutral complexes were obtained by combining DNA and liposomes in such amounts that the positive charge contributed by the cationic liposomes was equal to the number of negative charges present in the plasmid DNA. The formation of neutral DNA/liposome particles is expressed as equivalent: one equivalent DOGS corresponding to 1 nmol DOGS per $\mu \mathrm{g}$ of plasmid DNA [14]. To this complex 1.0-1.5 equivalent DOPE (corresponding to 1.0-1.5 nmol) was added. In the case of Lipofectin, formulated as DOTMA/DOPE (1:1), the complexes used for transfection were obtained by adding DNA in the same ratio as for DOGS/DOPE.

\subsection{Reporter gene expression in cell lines and primary cultures}

First, the ability of DOGS/DOPE and DOTMA/DOPE to mediate gene transfer in cell lines was assessed. Table 1

Table 2

Expression of pRSV/luc and protein content measured in $3 \mathrm{T3}$ and A549 cells after transfection with increased concentration of DNA mixed with DOGS/DOPE (a) and DOTMA/DOPE (b) a

\begin{tabular}{|c|c|c|c|c|}
\hline \multicolumn{5}{|c|}{ (a) DOGS/DOPE } \\
\hline \multirow[t]{2}{*}{$\overline{\mathrm{DNA}(\mu \mathrm{g})}$} & \multicolumn{2}{|l|}{$3 \mathrm{T3}$} & \multicolumn{2}{|l|}{ A549 } \\
\hline & $\begin{array}{l}\text { luciferase act. } \\
(\mathrm{U} / \mathrm{mg})\end{array}$ & $\begin{array}{l}\text { protein content } \\
(\mathrm{mg} / \mathrm{ml})\end{array}$ & $\begin{array}{l}\text { luciferase act. } \\
(\mathrm{U} / \mathrm{mg})\end{array}$ & $\begin{array}{l}\text { protein content } \\
(\mathrm{mg} / \mathrm{ml})\end{array}$ \\
\hline 2 & 84169 & 3.0 & 426 & 4.3 \\
\hline 4 & 187787 & 3.4 & 593 & 4.3 \\
\hline 6 & 114331 & 3.0 & 966 & 3.3 \\
\hline Control $^{\mathbf{a}}$ & 125 & 2.8 & 74 & 4.0 \\
\hline Control ${ }^{b}$ & 96 & 2.8 & 65 & 4.5 \\
\hline
\end{tabular}

(b) DOTMA/DOPE

\begin{tabular}{lllll}
\hline DNA $(\mu \mathrm{g})$ & $3 \mathrm{T3}$ & & A549 \\
\cline { 2 - 4 } & $\begin{array}{l}\text { luciferase act. } \\
(\mathrm{U} / \mathrm{mg})\end{array}$ & $\begin{array}{l}\text { protein content } \\
(\mathrm{mg} / \mathrm{ml})\end{array}$ & $\begin{array}{l}\text { luciferase act. } \\
(\mathrm{U} / \mathrm{mg})\end{array}$ \\
\hline 2 & 187818 & 3.0 & 1241 & 1.7 \\
4 & 395185 & 1.4 & 4574 & 1.2 \\
6 & 653889 & 0.5 & 6848 & 0.9 \\
Control $^{\text {b }}$ & 299 & 1.2 & 68 & 3.8 \\
Control $^{\text {c }}$ & 91 & 3.0 & 69 & 4.4 \\
\hline
\end{tabular}

\footnotetext{
a The luciferase activity is expressed as $\mathrm{U} / \mathrm{mg}$. The cytotoxic effect of DNA/liposome treatment is determined by protein content reduction (mg/ml) as compared to control. The results are the mean of two independent experiments.

${ }^{b}$ Cells exposed to cationic lipid without DNA.

${ }^{c}$ Cells exposed to buffer only.
} 
illustrates the percentage of $\beta$-galactosidase expressing cells in $3 \mathrm{~T} 3$ and A549 cell cultures transfected with pCMVNLS/lac7. (Fig. 1a) complexed to DOGS/DOPE or DOTMA/DOPE. In each cell line a dose-dependent transfection efficiency was measured with differences of 0.4-3.3 in the percentage of positive cells between the two types of liposomes. In all experiments, we found that the level of transfection efficiency in the human lung epithelial cell line was 7 - to 30-times lower as compared to the mouse lung fibroblasts. To obtain a more accurate quantification of the gene transfer, a luciferase gene was used as reporter. The luciferase activity measured in 3 T3 and A549 cells transfected with increasing amounts of pRSV/luc (Fig. 1c) complexed to DOGS/DOPE or DOTMA/DOPE is shown in Table 2. Using either complex, the number of light units measured in A549 cells was 85-300-times lower than in $3 \mathrm{~T} 3$ cells, underscoring the results obtained with lacZ. In DOTMA/DOPE transfected cells, the marker gene expression was accompanied by a decreased protein content, which is considered a sign of cellular toxicity. This effect is consistent with the observation of diffuse cell detachment which was not observed in the cell cultures exposed to DOGS/DOPE.

In order to evaluate the efficiency of gene transfer in primary isolated epithelium, primary cultures of Rhesus monkey lung epithelium were used. In these cultures, the epithelial cells surrounding the explants formed a multilayer of various cell types. Ciliated cells, identified by the presence of active ciliary beating, were localized at the edge of the explants. In addition to ciliated cells, the presence of mucous and basal cells were demonstrated by immunohistochemical staining of human cytokeratin 18 (antibody RGE 53, Organon Teknika, Eindhoven, The Netherlands) and 5 and 8 (antibody RCK 102, Organon Teknika), respectively (data not shown). Transfected cells were detected in the cultures exposed to $1-16 \mu \mathrm{g}$ of pCMVNLS/lacZ (Fig. le) complexed to DOGS/DOPE or DOTMA/DOPE. The lac7-positive cells were localized at the periphery of the epithelial outgrowth (Fig. 3). The high intra- and inter-experimental variability of the number of transfected cells does not allow a precise estimation of the transfection efficiency, which ranged from $0.1-3 \%$. The highest numbers of lacZ-positive cells were detected in those cultures transfected with 4-5 $\mu \mathrm{g}$ of plasmid DNA complexed to DOTMA/IDOPE (Fig. 2). Increased amounts of the plasmid (10-50 $\mu \mathrm{g}$ ) and/or charge ratio did not result in higher numbers of lacZ-positive cells (data not shown). In contrast to pCMVNLS/lacZ, no gene expression was observed in primary trachea cultures after transfection with pRSV/luc (Fig. 1c) complexed to either DOTMA/DOPE or DOGS /DOPE.

\subsection{In vivo gene expression in mouse airways}

Under conditions applied in vitro, no in vivo gene transfer was observed in mouse airways. Based on the
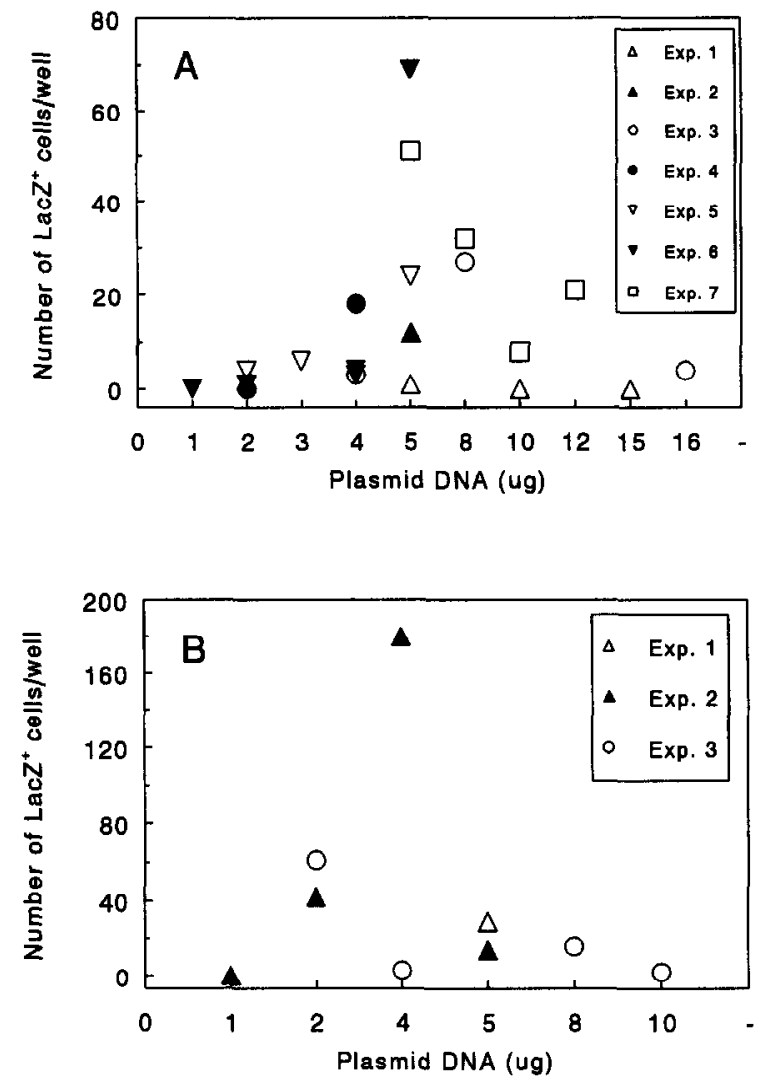

Fig. 2. Gene expression in primary trachea cultures mediated by DOGS/DOPE (A) and DOTMA/DOPE (B). The explants of Rhesus monkey trachea were seeded in 24-well plates. After 5 or 6 days the cultures were exposed to DOGS/DOPE or DOTMA/DOPE mixed with increasing amounts of plasmid DNA harboring the bacterial lacZ gene. The results are presented as number of positive cells per treated explant.

study of Hyde et al. [9], DNA-liposome charge ratios lower than 1.0 were investigated. After testing various DNA/lipid ratios $(0.06-0.90)$ and various DNA concentrations $(15-300 \mu \mathrm{g})$, lacZ-positive cells were detected only under the following conditions: (1) $30 \mu \mathrm{g}$ of pRSVNLS/lacZ (Fig. 1d) complexed to 0.4 equivalent DOTMA/DOPE $(n=3)$, and (2) $300 \mu \mathrm{g}$ of pCMVNLS/lacZ (Fig. 1a) mixed with DOGS/DOPE (charge ratio of 0.1$)(n=3)$. In each animal only few transfected cells were detected (approximately 5 cells per cross section, 6 sections per animal). The distribution of transfected cells was similar for both types of liposomes. LacZ-positive cells were present in the trachea and the main bronchi of the mice. No positive cells were observed in bronchioles, terminal bronchioles and alveoli suggesting a localization of transfected cells at the site of instillation. The light microscopical identification of the transfected cells showed that only ciliated cells were positive. Background lacZ staining in sections of the untreated control animals was detected only in the submucosal glands of the animals. No differences in mouse body weight were observed after liposome instillation. Furthermore, in none of the experimental groups evidence of lung inflammation 
Table 3

Luciferase activity detected in the airways of mice transfected with DOGS/DOPE or with Ad.CMV/luc virus ${ }^{\text {a }}$

\begin{tabular}{lll}
\hline Type of vector & Organ & Luciferase act. $(\mathrm{U} / \mathrm{mg})^{\mathrm{b}}$ \\
\hline pCMV/luc & trachea & 260 \\
& lung & 61 \\
Ad.CMV/luc & trachea & $3.9 \cdot 10^{6}$ \\
& lung & $5.7 \cdot 10^{4}$ \\
Control & trachea + lungs & 49
\end{tabular}

a The control mice received bidistilled water only.

${ }^{b}$ Results are expressed as mean of two animals.

was detected at the histomorphological level.

Luciferase activity in the mouse lungs after liposomemediated transfection was measured to quantify in vivo gene expression. No light emission was detected in the homogenate of mouse lungs after transfection with a low $(30 \mu \mathrm{g})(n=6)$ or a high $(400 \mu \mathrm{g})(n=6)$ amount of the pRSV/luc (Fig. 1c) complexed to either DOTMA/DOPE or DOGS/DOPE. In contrast, instillation of $300 \mu \mathrm{g}$ of $\mathrm{pCMV} /$ luc (Fig. 1b) complexed to 0.1 equivalent of DOGS /DOPE resulted in detectable light emission (Table 3). Increased luciferase activity was measured only in the trachea homogenates, while lung homogenates remained negative. The luciferase expression detected in the animals exposed to $10^{8}$ pfu of recombinant adenovirus was $10^{4}$ times higher than those treated with liposomes.

\section{Discussion}

This study shows that liposomes consisting of DOTMA/DOPE or DOGS/DOPE are able to mediate expression of lacZ and luciferase marker genes in mouse and human cell lines. DOGS has a higher cationic charge number in the headgroup of the molecule than DOTMA, favoring a strong interaction with the negative charge in the DNA molecules resulting in the formation of compact DNA/DOGS complexes [14]. This 'virus-like' particle, formed in an excess of cationic charge, is thought to cross cellular membranes in an efficient way [26]. In this study, an equimolar charge ratio was used to enable a direct comparison between the two types of liposomes. Under these conditions, it was found that DOGS/DOPE and DOTMA/DOPE were equally efficient in in vitro transfer of pCMVNLS/lacZ. Interestingly, higher in vitro gene expression was found after transfection with DOTMA/DOPE compared to DOGS/DOPE, using a $\mathrm{pRSV} /$ luc plasmid. These observations suggest that

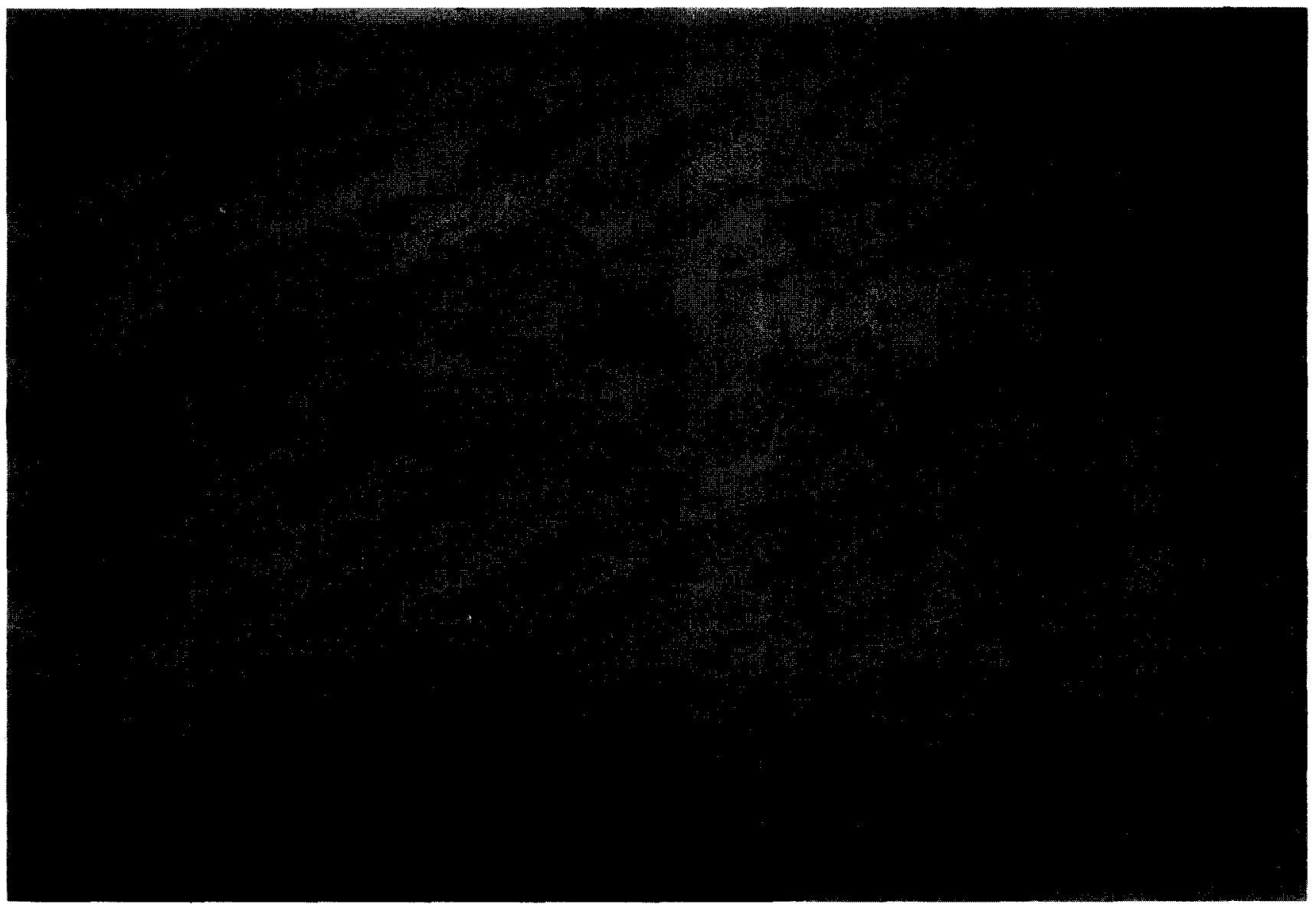

Fig. 3. Gene transfer in primary trachea cultures of Rhesus monkeys. Trachea explants were treated with DOTMA/DOPE complexed to $4 \mu \mathrm{g}$ of pCMVNLS/lacZ (Fig. 1e). The transfected cells (arrowheads) were detected in high number only in the periphery of the outgrowth. 
DOTMA/DOPE, although transfecting the same number of cells, is able to deliver a higher number of plasmids per cell compared to DOGS/DOPE.

Alternatively, DOTMA/DOPE and DOGS/DOPE are equally effective in gene delivery, but due to the strength of the interaction between DOGS and the plasmid, the release of DNA for transcription is impaired [12]. Both lipids were more effective in gene transfer to the murine 3T3 cells than to the human A549 cells. This cell line dependency is also reported by Behr et al. [27]. The reason of this observation is not established, but may be linked to the difference in cell cycle time of the cell lines. Since transfected DNA is probably transported inefficiently through the nuclear membrane during interphase $[28,29]$, it is likely that the breakdown of the nuclear membrane during mitosis is crucial to efficient entrance of the transfected DNA into the nucleus ([14], Dr. M. Wilke, unpublished data). Therefore, the more rapidly dividing 3T3 cells may have an advantage over the A549 cells. The dependence of the transfection efficiency on cell division may also explain why primary trachea cultures could be transfected only minimally. The presence of lacZ-positive cells in the edge of the outgrowth suggests that only proliferating cells expressed the marker gene. Although we can not exclude species and/or origin differences, our results indicate that cell proliferation might be an important factor in the efficiency of gene transfer.

In addition to the in vitro studics, DOTMA/DOPE and DOGS/DOPE were also assessed for their ability to mediate gene transfer in vivo. After intratracheal instillation both types of liposomes were demonstrated to mediate gene transfer of both lac $Z$ and luciferase marker gene in the mouse airways. The $\beta$-galactosidase positive cells detected in the trachea and main bronchi were identified as ciliated cells. In contrast to the in vitro results, these data would suggest that liposomes are able to mediate gene transfer in cells that are terminally differentiated and unable to divide. However, it is well possible that resting cells are induced to proliferate by the damage produced by the intratracheal instillation, giving rise to transfected ciliated cells. Consonant with the distribution of $\beta$-galactosidase positive cells, luciferase activity was confined to the upper airways after exposure to DNA/liposome complexes. When adenovirus was used as a vector, luciferase expression was detected both in trachea and lung. Moreover, gene expression was 1000 - to 10000 -times higher than when liposomes were used, confirming that adenoviruses are efficient tools for infection of the airway epithelia as demonstrated in both cotton rats and rhesus monkeys $[2,30]$. Our in vivo results contrast with studies which showed high gene expression after administration of DNA/liposome complexes to lung epithelium of rodents [6,31]. Our data on liposome-mediated transfer of luciferase, however, are comparable with those reported by Yoshimura et al. [7]. They demonstrated in mouse airways a luciferase activity of approx. $500 \mathrm{U} / \mathrm{mg}$ protein after intratracheal instillation of DOTMA/DOPE complexed with 200-400 plasmid DNA. These contrasting results may be explained by factors that are yet unknown, such as the method of preparation of the DNA/liposome complexes [12]. In order to obtain a conclusive evaluation of the potential of liposomes with respect to gene transfer, a direct comparison with adenoviruses was performed. Under our experimental conditions, liposomes were far less efficient than adenovirus, indicating that knowledge on the mechanism of transfection is necessary to improve in vivo gene transfer mediated by lipid vectors.

In conclusion, we have demonstrated that (a) DOGS or DOTMA can be used as vehicles for gene transfer; (b) in vitro, transfection efficiency mediated by DOTMA/DOPE is equal to that of DOGS/DOPE, while gene expression was slightly higher; (c) in vitro, transfection efficiency of cationic liposomes seems to be related to cell proliferation; (d) in vivo, DOGS and DOTMA are able to transfer marker genes into mouse upper airways after intratracheal instillation; (e) in vivo, transfection efficiency mediated by cationic liposomes was low as compared to the adenovirus infection.

\section{Acknowledgements}

We thank Dr. R.D. Gerard (Southwestern Medical Center, University of Texas) for generously providing Ad.CMV/luc virus, J.M.A. Kohout (TNO Medical Biological Laboratory, Rijswijk, The Netherlands) for technical assistance, and Dr. J.J.M van de Sandt (TNO Nutrition and Food Research Institute, Zeist, The Netherlands) for the stimulating discussions. This work has been supported by the Association Francaise pour la Lutte contre la Mucoviscidose (AFLM), Paris.

\section{References}

[1] Bout, A., Perricaudet, M., Baskin, G., Imler, J.-L., Scholte, B.J., Pavirani, A. and Valerio, D. (1994) Hum. Gene Ther. 5, 3-10.

[2] Bout, A., Imler, J.L., Schultz, H., Perricaudet, M., Zurcher, C., Herbrink, P., Valerio, D. and Pavirani, A. (1994) Gene Ther. 1, 1-10.

[3] Crystal, R.G., McElvaney, N.G., Rosenfeld, M.A., Chu, C., Mastrangeli, A., Hay, J.G. Brody, S.L. Jaffe, H.A., Eissa, N.T. and Danel, C. (1994) Nature Genet. 8, 42-51.

[4] Brody, S.L. Metzger, M. Danel, C., Rosenfeld, M.A. and Crystal, R.G. (1994) Hum. Gene Ther. 5, 821-836.

[5] Yang, Y., Nunes, F.A., Berencsi, K., Furth, E.E., Gönczöl, E. and Wilson, J.M. (1994) Proc. Natl. Acad. Sci. USA 91, 4407-4411.

[6] Bout, A., Valerio, D. and Scholte, B.J. (1993) Exp. Lung Res. 19, 193-202.

[7] Yoshimura, K., Rosenfeld, M.A., Nakamura, H., Scherer, E.M., Pavirani, A., Lecocq, J.-P. Crystal, R.G. (1992) Nucleic Acids Res. $20,3233-3240$.

[8] Nabel, E.G., Gordon, D., Yang, Z.Y., Xu, L., San, H., Plautz, G.E., Wu, B.Y., Gao, X., Huang, L. and Nabel, G.J. (1992) Hum. Gene Ther. 3, 649-656. 
[9] Hyde, S.C., Gill, D.R., Higgins, C.F., Trezise, A.E.O., MacVinish, L.J., Cuthbert, A.W., Ratcliff, R., Evans, M.J. and Colledge, W.H. (1993) Nature 362, 250-255.

[10] Caplen, N.J., Alton, E.W.F.W., Middleton, P.G., Dorin, J.R., Stevenson, B.J., Gao, X., Durham, S.R., Jeffery, P.K., Hodson, M.E., Coutelle, C., Huang, L., Porteus, D.J., Willamson, R. and Geddes, D.M. (1995) Nature Med. 1, 39-46.

[11] Alton, E.W.F.W., Middleton, P.G., Caplen, N.J., Smith, S.N., Steel, D.M., Munkonge, F.M., Jeffery, P.K., Geddes, D.M., Hart, S.L., Williamson, R., Fasold, K.I., Miller, A.D., Dickinson, P., Stevenson, B.J., McLachlan, G., Dorin, J.R. and Porteus, D.J. (1993) Nature Genet. 5, 135-142.

[12] Smith, J.G., Walzem, R.L. and German, J.G. (1993) Biochim. Biophys. Acta 1154, 327-340.

[13] Behr, J.P., Demeneix, B., Loeffler, J.P. and Mutul, J.P (1989) Proc. Natl. Acad. Sci. USA 86, 6982-6986.

[14] Barthel, F., Remy, J.S., Loeffler, J.P. and Behr, J.P. (1993) DNA Cell Biol. 12, 553-560.

[15] Felgner, P.L. and G.M. Ringold (1989) Nature 337, 387-386.

[16] MacGregor, G.R. and Caskey, C.T. (1989) Nucleic Acids Res. 17, 2365.

[17] de Wet, J.R., Wood, K.V., DeLuca, M., Helinski, D.R. and Subramani, S. (1987) Mol Cell. Biol. 7, 725-737.

[18] Boshart, M., Weber, F., Jahn, G., Dorsch-Häler, K., Fleckenstein, B. and Scaffner, W. (1985) Cell 41, 521-530.

[19] Sambrook, J., Fritsch, E.F., Maniatis, T. (1989) Molecular Cloning, A Laboratory Manual, Cold Spring Harbor Laboratory Press, Cold Spring Harbor.
[20] Herz, J. and Gerard, R.D. (1993) Proc. Natl. Acad. Sci. USA 90 2812-2816.

[21] Rich, D.P., Couture, L.A., Cardoza, L.M., Guiggio, V.M., Armentano, D., Espino, P.C., Hehir, K., Welsh, M.J., Smith, A.E. and Gregory, R.J. (1993) Hum. Gene Ther. 4, 461-476.

[22] Stratford-Perricaudet, L. and Perricaudet, M. (1991) In Human Gene Transfer (Cohen-Haguenauer, O. and Boiron, M., eds.), pp. 51-61, Inserm/John Libbey Eurotex, Paris.

[23] Chevillard, M., Hinnrasky, J., Zahm, J-M., Plotkowski, M.-C. and Pushelle, E. (1991) Cell. Tissue Res. 264, 49-55.

[24] Thepen, T., Rooijen. N. and Van Kraal, G. (1989) J. Exp. Med. 170 499-509.

[25] Bradford, M.M. (1976) Anal. Biochem. 72, 248-254.

[26] Loeffler, J.P. and Behr, J.P. (1993) Methods Enzymol. 217, 599-618.

[27] Behr, J.P. (1994) Bioconj. Chem. 5, 382-389.

[28] Zabner, J., Fasbender, A., Moninger. T. and Welsh, M.J. (1994) Ped Pulm. 10 (Suppl.), 223 (abstract).

[29] Vitadello, M., Schiaffino, M., Picard, A., Scarpa, M. and Schiaffino, S. (1994) Hum. Gene Ther. 5, 11-18.

[30] Zabner, J., Petersen, D.M., Puga, A.P., Graham, S.M., Couture, L.A., Keyes, L.D., Lukason, M.J., St.George, J.A., Gregory, R.J., Smith, A.E. and Welsh, M.J. (1994) Nature Genet. 6, 75-83.

[31] Logan, J.J., Bebock, Z., Walker, L.C., Peng, S., Felgner, P.L., Siegal, G.P., Frizzell, R.A., Dong, J., Howard, M., Matalon, S., Lindsey, J.R., DuVall, M. and Sorscher (1995) Gene Ther. 2, $38-49$. 